\title{
National projects as a way to solve the problems of economic and digital disparities in different areas and regions
}

\author{
Ekaterina Khalimon \\ Project Management Department \\ State University of Management \\ Moscow, Russia \\ 0000-0002-9480-3466
}

\author{
Irina Brikoshina \\ Project Management Department \\ State University of Management \\ Moscow, Russia \\ 0000-0002-1765-0750
}

\author{
Mariya Guseva \\ Project Management Department \\ State University of Management \\ Moscow, Russia \\ 0000-0002-5576-6164
}

\author{
Irina Kogotkova \\ Project Management Department \\ State University of Management \\ Moscow, Russia \\ 0000-0003-1928-0076
}

\author{
Sergej Nikitin \\ Project Management Department \\ State University of Management \\ Moscow, Russia \\ 0000-0002-7855-8130
}

\begin{abstract}
This article is devoted to the study of trends in the development of project management in Russia and substantiation of the importance and needs for its application at the level of public authorities in the form of priority national projects and programs aimed at ensuring the breakthrough scientific, technological and socio-economic growth. Projects have been considered from a perspective of a whole society and the state in Russian Federation. The conducted study provides the meta-analysis of contemporary statistical data from multiple international scientific research, strategic state documents and project reports. The data collected shows important practical insights into project management application as a way to solve the problems of economic and digital disparities in different regions within a country. In the framework of the conducted research some risks were identified and analyzed, and as a result, ways of solving potential and emerging problems are proposed.
\end{abstract}

Keywords-national projects, project management, economic and digital disparities, tax burden, sources of funding, science cities, eco-industrial park.

\section{INTRODUCTION}

Today, methods of project management play a crucial role in the execution of strategic economic plans for creation of digital innovative products not only by corporations, companies, firms, but also by governments for the implementation of their programs of socio-economic development, involving a high level of organization, systematic approach, careful planning and competent management. They are an integral part of all transformations and contain the fundamental principles of effective management of transformation processes.

The accumulated methodological base uses practical knowledge, experience and all the necessary tools with tested economic and mathematical models of development, proving that project management is an effective mechanism of the market economy.

\section{CURRENT TRENDS IN PROJECT MANAGEMENT IN RUSSIA}

Project management started to develop in Russia and abroad almost simultaneously in the '30s. It was the period of development of national projects of industrialization of the whole country.

In the Soviet Union, the need for integrated planning was associated with the projects, unprecedented in scale, undertaken at that time by the state, such as the Dnieproges, the construction of the all-Russian electrification system (GOELRO), the development of coal and iron ore deposits, the creation of large territorial-industrial complexes, the construction of Turksib, the development of oil resources of the Volga region, the creation of a metallurgical base in the East of the country, the construction of the "Big Volga" [1], the creation of the Ural-Kuznetsk complex, etc.

Later developed methodology of network planning and management is still the core of modern methods of project management. It was actively used, first of all, in space and aviation (for example, in the 1970s when working on the project of reusable aerospace system "Spiral", in the 1980s when developing and implementing an innovative project to create a winged spacecraft "Buran" [2]), as well as in the construction of industrial complexes, factories, ports, buildings, hydroelectric power plants, transport networks.

In the early 1990s, Russia entered the project management world and became a full member of the project management community [3]. In 1996, at the State University of Management, the first project management department in Russia was established, which immediately became a major centre of educational and research activities, attracting the largest scientists and talented young professionals.

In addition, Internet, computer technology, globalization and international relations between companies have had a positive impact on the implementation of joint global projects (such as the 
joint program of the Russian Federation and the Republic of Kazakhstan "Baiterek" [4]; developed by Russia and China international project for the construction of a transport highway through the countries of Central Asia from China to Europe "One belt - one road" [5]), which are extremely complex and risky.

Currently, project management in Russia is returning to its origins - to the level of public administration. That is dictated by the need to implement the project approach in the implementation of large and long-term projects initiated by the country's leadership [6]. President of Russia Vladimir Putin has often talked "about the need to introduce modern administrative technologies to solve specific tasks, about the need for dissemination of best practices, alignment mechanisms, training and engaging people with project thinking" [7].

In 2016 the "Council under President of the Russian Federation for strategic development and priority projects" [7] was created in order to ensure interaction between the Federal bodies of state power, bodies of local self-government, public associations, scientific and other organizations to solve issues related to the implementation of strategic plans and priority national projects of the Russian Federation.

In July 2017 the Russian government developed and approved the program "Digital Economy of the Russian Federation" [8], which is designed to update all economic activities of the country and maintain a productive environment for the transition of the country's economy to the level of new technologies. According to this program, the implementation of the digital economy model is provided in five areas: "Information infrastructure", "Information security", "Regulatory", "Formation of research competencies and technological reserves" and "Personnel and education" [9]. The implementation of this program will allow to quickly process digital data and effectively use it in many types of production activities and services.

In 2018, the "Council under the President of the Russian Federation for strategic development and priority projects" was renamed to the "Council under the President of the Russian Federation for strategic development and national projects" [10]. Its main purpose is to make a breakthrough in the economy, infrastructure, technology, science and social sphere in order to ensure the well-being and new quality of life of Russian citizens, ample opportunities for selfrealization of each person, to strengthen the competitiveness of the country, to achieve leadership in those areas that will determine the future of Russia and the world. In a short time, a lot of difficult work was carried out, and national projects were prepared. They set targets and practical mechanisms for their achievement and the amount of funding. Special attention was paid to the system of monitoring the implementation of national projects and programs.

Active participation of state-owned companies is mandatory in the development projects. They are expected to elaborate proposals for the financial, technological, scientific and human contribution to the programs and projects of the breakthrough.

It is expected to implement three portfolios:

1) projects proposed by business and other Federal agencies;

2) projects proposed by the business itself for joint work with the state;

3) business projects that meet development priorities, but do not require state support in the framework of national projects.

Within six years, about 28 trillion rubles will be allocated to national projects from all sources [11]. To date, this is a very large figure. However, clear and competent planning of all upcoming events should allow consolidating the resources of the state, regions, business: they should work within the country and for its development, become an incentive for industry, science and education.

That means that all the necessary technology, software and equipment will be created in Russia, providing a high level of localization.

\section{ON THE TASKS OF BREAKTHROUGH NATIONAL PROJECTS OF THE RUSSIAN FEDERATION}

Back in 2005, the President of Russia initiated four priority national projects: "Health", "Education", "Housing" and "Development of the agro-industrial complex" [12]. Each of them contains a number of subprograms (subprojects), which are designed to modernize the social infrastructure of Russian society, improve the quality of life of Russian citizens [12].

The peculiarity of the projects is in their innovative orientation. State support is given to those areas of development that are associated with the use and implementation of advanced technologies.

The results of the four national projects had a significant positive impact on the development of the material and technical infrastructure of the relevant industries and gave impetus to economic development in the regions. But for the long term that was not enough. In the considered areas, there was an institutional change.

In 2018 the Russian Government introduced passports of national projects to the Council under the Russian President for strategic development and national projects in 12 areas of strategic development, established by the Decree of the President of Russia from May 7, 2018 No. 204 "On the national goals and strategic objectives development of the Russian Federation for the period until 2024" [13]: demography, health, education, housing and urban environment, ecology, safe and quality roads, productivity and support employment, science, digital economy, culture, small and medium enterprises (SMEs) and support for individual entrepreneurship, international cooperation and exports. The developed project passports comprehensively reflect the activities 
to achieve the national goals and targets set in the Decree.

The press began to call that Decree "superdecree" $[14,15,16]$, as the President outlined there the country's development, the ideology of a breakthrough. National projects are aimed at ensuring the breakthrough scientific, technological and socioeconomic development of Russia, increasing the population of the country, improving living standards, creating comfortable living conditions, opportunities for self-realization and disclosure of talent of each person. Russia will also have to enter the top 5 largest economies in the world while maintaining macroeconomic stability.

The Government managed to find more than 13 trillion rubles for the implementation of the first four national projects since 2005 within six years. For 2019-2021 within the framework of national projects identified in 2018, it is proposed to allocate 5693154 million [17].

Now the task of the Ministry of Finance and the Ministry of economic development is to find all the necessary funds for the execution of the "superdecree" of the President. The implementation of all tasks requires about 25 trillion rubles. In order to solve this problem, the government should ensure that additional revenues from the Federal budget generated during its execution are allocated to the implementation of national projects (programs) as a priority.

"The vitality of our country, the energy of its development, its future depends on their (national projects) achievement without exaggeration" [18], said the Russian President at the meeting of the Council for strategic development and national projects in October 2018, expressing confidence that Ministers are fully aware of the scale and content of these tasks.

Describing the signed decree, it can be stated that it provides for a return to the system of state strategic planning, program-target management and system analysis of all socio-economic processes and phenomena, which is the basis of project-oriented state management.

Today, the government faces the task of developing detailed plans as quickly as possible to implement the super-decree on the national goals and strategic objectives of Russia's development for the period up to 2024. In fact, it is about the creation of new national projects. The designated goals, objectives, planned indicators (performance criteria) are specific, require the elaboration of mechanisms for their implementation, including resource support and calculation of risks. For this purpose, non-standard approaches in planning and management are required to reach a modern style of management, providing maximum openness of ministries and departments, constant dialogue with people, justification of their actions. That should ensure to a large extent the success of coordinated actions of the government. In addition, it is expected to involve the greatest possible number of citizens in the realization of the objectives of development, to strengthen their commitment to work together to achieve the desired goals, so that the ideology of the breakthrough should be clear to people. "National projects are designed to unite citizens to achieve the breakthrough. It is necessary at a turning point, a milestone in the history of our country" [11], said the President and stressed that "there can be no reference to the circumstances that will prevent this work from being carried out in the prescribed time" [11].

\section{ON THE PROBLEMS OF ECONOMIC (SPATIAL) AND DIGITAL DISPARITIES IN REGIONS}

Understanding the obstacles to the development of a country begins with the scale of its territory and Federal subjects, as well as the mechanism by which they are managed.

Located in Europe and Asia, Russia has the largest area in the world, stretching from the Northern harsh and resource rich latitudes to the southern life friendly regions. In Soviet times, there was a program to settle the remote Eastern territories of the country in order to create city-forming enterprises, centers of industry and urban infrastructure for comfortable life for families of immigrants.

During several years of implementation of the program, such economic centers were created, but their management was ineffective.

A number of authors [19], conducting a study on the problem of economic (spatial) disparities in various countries of Europe and Central Asia, concluded that this indicator reaches the highest value in the Slovak Republic, Tajikistan and Russia, and the lowest - in Denmark. In Europe, the differences are highest in Greece, Italy and Spain.

There are also huge differences in living standards in the Russian regions. Thus, the standard of living of households in the Sakhalin region (with the highest gross regional product per capita) is similar to the standard of living in Singapore, and the standard of living of households in Ingushetia (with the lowest gross regional product per capita) is closer to the standard of living in Honduras [19]

In Europe and Central Asia the level of education and erudition of the population is the highest in the world. However, there are still problems with access, especially among certain groups of people and geographical areas. Thus, children of the same class in the same country have access to quality education, depending on where they live. According to the Programme for International Student Assessment (PISA) in 2015 the largest gap in education between citizens and villagers is observed in Bulgaria and Moldova, followed by the Slovak Republic and Romania [20].

The basic component is that only a country that pays constant attention to the training of specialists with modern knowledge can be competitive in the world. According to international estimates published 
by the Organization for Economic Co-operation and Development (OECD), Russia has the highest number of students per ten thousand inhabitants. In the country, higher education is an established tradition. In addition, receiving a bachelor's degree, a specialist, many go to study further, acquiring a second higher education, a master's and a $\mathrm{PhD}$ degree. This has become a necessity for the versatile development and professional abilities of individuals.

However, even in the case of eliminating problems with obtaining public goods, differences in rates of economic development in different regions can't be overcome if problems with safe roads, public transport and welfare of residents for free movement between settlements are not solved. That is the problem of «horizontal disparities», containing obstacles to communication and interaction between economic entities.

The other problem is «spatial disparity», as it has a big impact on a country's economy. If some regions are systematically deprived of economic benefits and new digital technologies, because of lower skills of their representativies, limited labour mobility and other problems, the regions' spatial and digital disparities will expand, and an increasing proportion of the population will be left behind in educational, cultural and socio-economic development.

Income disparities persist in most European and Central Asian countries. National indicators of wellbeing hide significant differences between several regions. However, studying this phenomenon in different regions, it turns out that digital disparity is common for several countries.

In the analysis of the overall level of digitalization conducted in 2017 by an international company working in the field of management consulting McKinsey \& Company, an indicator characterizing the level of digitalization of countries was derived - the International Digital Economy and Society Index (IDESI) [21]. It was derived on the basis of 24 indicators to assess the level of use of digital technologies in the daily activities of consumers, companies and government agencies, as well as the provision of IT infrastructure and digital technologies.

Their report showed that Russia achieved some success in digitalizing its economy being among leaders of the "active followers" group by investing in the expansion of IT infrastructure and the integration of digital technologies in government, but far behind the leading countries, especially in terms of digitalization of companies.

McKinsey also notes that the digital economy of Russia is characterized by the so-called "digital disparity" - disproportions in the development of its technologies among regions. According to CNews Analytics, Moscow accounts for $40 \%$, and 10 of 86 regions account for $80 \%$ of total government spending on information technologies [22]. The level of digitalization of Moscow and St. Petersburg will be appropriate to compare with world leaders, while the regions are more comparable to the States of the categories of "active followers" and "lagging followers". The digital divide created by the existing economic and social gap between the capital and the regions also contains opportunities to overcome it through the rapid and relatively inexpensive scaling inherent in digital solutions and services.

\section{PROBLEMS}

To achieve the goal of bringing the Russian economy to the sixth technological order - to the level of digitalization and high technologies - the government needs to ensure the inflow of planned targeted investments.

A. The problem of underfinancing of national projects can become a big threat and a decisive moment in work on projects. To date, analyzing the experience of various countries on unrealized or frozen projects, as well as on those projects that have remained at the stage of conceptualization (such as the project of creating the spacecraft "Pole", the project of soaring cities "Ninth sky", the project of the first wireless TV tower "Wardencliff", the project of connecting Eurasia and North America by a railway tunnel, the project of restoring the "Ghost town" Kadykchan, the project of the highest hotel "Rügen", the project of developing laser weapons in the USSR, Walt Disney's EPCOT city project, the futuristic engineering project of Atlantropa, the Russian dam construction project through the Bering Strait, the project of the skyscraper "Russia", the project "Barmingrad", the project of the building of the Central house "Aeroflot", the project "Venus" of Jacques Fresco, the military project "Wings of tank", the project of the turn of Siberian rivers, the architectural project "Monument to world suffering" and others), it can be stated that the main reason for their non-realization was the lack of funding (in a number of projects the lack of funding was not the root cause, but a consequence of other global political or economic problems).

Under the statements of the Head of the accounts chamber of the Russian Federation, the threat of underfunding of national projects in 2019-2021 could be 1 trillion rubles [23]. The draft budget for three years at the expense of the Federal budget for the financing of national projects provides 5,693 trillion rubles. Within the national projects, 1,550 trillion rubles have not been distributed yet. Part of these funds will go in the form of subsidies to the Federal subjects, and it remains unclear how much they will get within these goals. In addition, the deviation from the passports of national projects is quite significant from the total.

This situation is not new for the government. Thus, according to the project "Digital economy" deviation from financial indicators is $55 \%$, the project "Safe and quality roads" - 32\%, the project of "Small and medium-scale businesses" - 31\%, "International cooperation and exports" - 29\% [23]. Deviations are almost in all national projects. 
There are two possible solutions to this problem:

1. project passports for 2019-2021 should be aligned with the budget and estimates reduced.

2. the launch of a number of projects during 20192021 should be slowed down or postponed.

Compliance of passports and volumes of financing in the budget is an important issue. If the deadline for such large-scale projects is shifted, there is a risk of not implementing them at all and not achieving the planned goals.

In addition, in the report of the Minister of economic development On the priorities of socioeconomic development of Russia and the implementation of national projects on small business, it was noted that for their implementation from the Federal budget will be allocated: 1.7 trillion rubles in 2019, 1.9 trillion rubles - in 2020 and 2.1 trillion rubles - in 2021, but no more than $10 \%$ of funds are now brought to the regions [24]. The Minister explained that the slow spending of Federal money in the first decade of a year is a normal situation, as it takes time to process the documents.

B. Here comes another problem: the slow pace of development of budget money can lead to the failure of the implementation of national projects. If the planned tasks are in a stage of waiting for financing, in the long term, these tasks cannot be done even with the allocation of funds. This is due to the fact that as time passes, a performer, requirements for a task, a required amount of funding and resources can change.

The solution may be to determine the pace of project implementation and remove barriers at the level of public administration that hinders this development. It is necessary to reach other, completely new indicators of economic growth, but for this there must be a different responsibility of all participants of project teams.

\section{SOURCES OF FUNDING FOR NATIONAL PROJECTS}

The tax system is based on certain principles regulated by the rules of law of social relations, emerging in connection with the establishment and collection of taxes and fees [25]. The most important characteristic of the tax system is its efficiency which can be achieved with a certain amount of funds accumulated by the state:

- costs of tax administration are minimal;

- a distorting effect of taxes on the behaviour of taxpayers is minimal.

As a quantitative characteristic of the efficiency of a tax system can be used such economic indicator as to the tax burden (TB), which determines the share of income paid to the state in the form of tax payments. The generally accepted indicator of the TB in the country as a whole is the share of taxes in GDP: $\mathrm{TB}=(\mathrm{T} / \mathrm{GDP}) \times 100 \%$, where $\mathrm{T}-$ all tax payments, including contributions to state off-budget funds and customs payments.
Using the official data provided by the Federal statistics service of ROSSTAT presented on their website [26], the tax burden in Russia for 2008-2018 was:

TABLE I. TAX BURDEN

\begin{tabular}{|c|c|c|c|c|c|c|c|c|c|c|c|}
\hline dicator & $\stackrel{\infty}{\stackrel{\overbrace{}}{్}}$ & ڤ્సે & $\stackrel{ }{\vec{乛}}$ & $\overline{\bar{N}}$ & $\stackrel{)}{\widetilde{d}}$ & 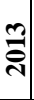 & $\underset{\vec{d}}{\mathbb{d}}$ & 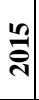 & 를 & 클 & $\stackrel{\infty}{\overrightarrow{0}}$ \\
\hline $\begin{array}{c}\text { Revenues } \\
\text { - total } \\
\text { (Billion } \\
\text { RUB) }\end{array}$ & $\begin{array}{l}+ \\
\text { ஸे } \\
8 \\
8\end{array}$ & $\begin{array}{l}\hat{2} \\
2 \\
2\end{array}$ & $\begin{array}{l}0 \\
0 \\
0 \\
0\end{array}$ & $\begin{array}{l}+ \\
n \\
n \\
\infty \\
0 \\
\end{array}$ & 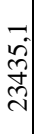 & 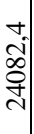 &  & $\begin{array}{l}0 \\
\text { ป̂. } \\
\text { ลे } \\
\text { ปे }\end{array}$ & $\begin{array}{l}n \\
\infty \\
\infty \\
\text { c }\end{array}$ & \begin{tabular}{l}
\multirow{2}{0}{} \\
0 \\
0 \\
$m$
\end{tabular} & 응 \\
\hline $\begin{array}{c}\text { in } \\
\text { percent } \\
\text { of GDP }\end{array}$ & $\begin{array}{l}+ \\
\infty \\
\infty\end{array}$ & $\begin{array}{l}\infty \\
\stackrel{+}{+}\end{array}$ & mi & $\begin{array}{c}+ \\
\infty \\
\infty \\
m\end{array}$ & $\frac{a}{m}$ & ही & $\frac{n}{n}$ & m. & $\begin{array}{l}\infty \\
\text { m. }\end{array}$ & mे & $m$ \\
\hline
\end{tabular}

Analyzing the data from table 1, the TB in Russia in the periods 2009-2011, 2013-2014 and 2016-2018 tended to increase (on average from 34.8 to $35.6 \%$ ). A strong decline occurred in 2008 - 2009, which was due to the unstable financial and economic situation not only in Russia but also in many other countries (the first wave of the crisis). A similar situation occurred in 2014-2016, which can be explained as the effect of the "second wave of the crisis".

However, despite these fluctuations, the average tax burden in the Russian Federation (35.8\%) is close to developed economies, not to developing ones (see Fig.1 [27]). In the Republic of Serbia, this indicator reached $38.5 \%$ in 2017 [28], although it also applies to develop countries according to the International Monetary Fund.

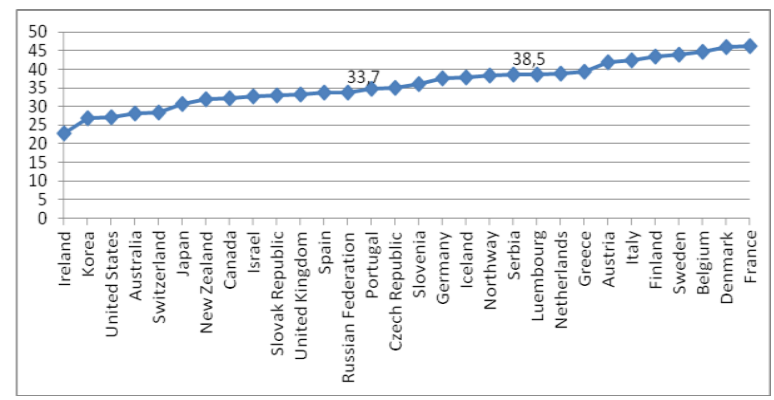

Fig. 1. TB in 2017 in developed countries, Russia and Serbia. (\%)

Today, the Russian tax system functions in such a way that it makes production in Russia unprofitable and destroys the Russian industry. By the end of 2019, TB is likely to grow by a few more points. Tax laws are complex and confusing, changes in laws occur on average every year, and there is no free legal support for SMEs. Talking about the support for SMEs, the government does not recognize that the main brake on the development of the production and agricultural sectors is associated with the tax burden.

As a result, the government needs to resolve a difficult issue: on the one hand, reducing the tax burden on resident companies engaged in all sectors of the economy will give impetus to their rapid development in Russia, increase their number, and, 
accordingly, the sources of tax revenues will become more. On the other hand, easing the tax burden will dramatically reduce the revenue side of the budget, which is not acceptable for the government.

\section{THE DEVELOPMENT OF SCIENCE CITIES AND ECO- INDUSTRIAL PARKS - AS A COMPREHENSIVE SOLUTION TO THE PROBLEMS OF INEQUALITY REGIONS}

Today's socio-economic systems in developing countries are increasingly reduced to a model of circular development. The closed-loop economy proposes a shift from linear to cyclical (or closed-loop) systems by promoting resource savings and increasing resource productivity at all stages of production, distribution and consumption [29].

The main thing for the successful management and implementation of programs of socio-economic development of territories and enterprises are human resources because they are both main executors of development programs, and main participants in the process of consumption of the results. In addition, people are the bearers of innovations (new ideas, bringing them to results in the areas of social, economic and environmental security), which can make the greatest contribution to the socio-economic development of the regions.

In 2015, the Federal law №100 “On amendments to the Federal law "On the status of the science city of the Russian Federation" and the Federal law "On science and state scientific and technical policy" were developed [30]. After that, in 2018, the Department of special programs, development of state scientific centers and science cities was established in the Ministry of science and higher education of the Russian Federation. The allocated budget funds are provided to implement the Strategy of socio-economic development of science cities, contributing to the:

1) growth of scientific and production complex of the science city, including SMEs;

2) growth of production of high-tech and (or) innovative goods and services in accordance with the priority directions of development of science and technology of the Russian Federation;

\section{3) growth of science city infrastructure.}

An important factor in the rapid development of science cities is the increase in human resources and in quality of their education, which will require the implementation of a number of priority projects for the development or conversion of existing and external attraction of highly qualified and active human resources, as well as the implementation of a number of social programs to create an attractive environment and retain these resources.

On the example of activities of the Russian science city Troitsk on the strategy of socio-economic development by 2020-2025, the following projects from various spheres should be implemented: the project "School of the future" for 2100 pupils; the project "Youth IT-center"; the project "Development of the transport complex"; the project for the creation and development of interuniversity scientific and educational center; the project "Architecture of new carbon materials", which contains a plan for experimental studies; the project "Diamond materials for extreme electronics and x-ray optics", involving experimental studies on real x-ray optical elements; the project "Instrument-making for the study of materials at the nanoscale and certification of diamond raw materials"; the project "Drilling and processing tools for import substitution"; the project "Troitsk numass", in the framework on which has already been received the world's best limits on the existence of a new type of particle is the sterile neutrino in the mass range $0.1-2 \mathrm{keV}$.

In addition, special attention on the part of public administration deserves development in the regions, science cities, industrial parks, industrial clusters, ecoindustrial parks. On-site scientific, research and/or educational activities can be carried out that correspond to the basic meaning and function of the idea of creating eco-industrial parks [29].

\section{CONCLUSION}

Having conducted research of several scientific sources, international reviews, on the basis of actual practical data and statistic presented in this article, the following conclusion can be done:

As a new stage in the development of project management in Russia can be called the development of national projects at the state level, the implementation of which requires: close cooperation of the state, large companies, SMEs and people; a new management approach; a huge amount of money and a serious responsibility of all participants. It is expected that their implementation will stimulate the development of industry, production, science and education in various regions of the country.

Today, the government faces the task of developing detailed plans as quickly as possible to implement the decree on national goals and strategic objectives of Russia's development for the period up to 2024. Analyzing the risks and obstacles that may arise in the development of the country in the implementation of breakthrough national projects, the difficulties associated with the geographical location of the regions and the difficulties of managing a large territory come to the first place. These factors have given rise to problems of economic (spatial) and digital disparities, which occur in different regions of different countries around the world.

In addition, the Government has already fixed the problem of underfunding of national projects and the slow pace of budget development, which can become a big threat and a decisive moment in work on projects. This issue is currently under consideration at the level of public administration. The solution may be to determine the pace of project implementation and remove barriers at the level of public administration that hinders this development. Another difficult issue related to the provision of financing for national 
projects should be resolved taking into account the adjustment of the tax burden on resident companies engaged in all sectors of the economy.

Special attention from the public administration deserves the development in the regions of both science cities and industrial parks, industrial clusters, eco-industrial parks, which will give impetus to the development at the micro, meso and macroeconomic level.

\section{REFERENCES}

[1] G. P. Krasnoshchekov, G. S. Rozenberg, "Natural history aspects of the formation of the territory of the Volga basin," Proceedings of the Samara scientific centre of RAS. Vol. 1, 1999, pp. 108-115.

[2] N. L. Selvesuk, E. I. Smirnova, "Reusable space Shuttle Buran ships," Technical science in Russia and abroad: materials of VII International science conference. Moscow: Buki-Vedi, 2017, pp. 167-172.

[3] M. L. Razu, A. M. Lyalin, T. M. Bronnikova, "Project management: the fundamentals of project management," Moscow: KnoRus, 2018. 755 p.

[4] T. G. Imash, "Problems and prospects of bilateral cooperation of Kazakhstan and Russia in the exploration and use of outer space," Post-Soviet Studies, vol. 7, 2018, pp. 688-697.

[5] A. B. Bardal, "New silk road: opportunities and threats for the transport complex of the Far East of Russia," EKO, vol. 7 (505), 2016, pp.69-80.

[6] V. I. Dobrosotsky, "Improvement of project management in Russia,” Management Issues, vol. 6 (49), 2017, pp. 90-97.

[7] E. A. Khalimon, "On the application of project management in small and medium scale business," Actual problems of management in 2016: proceedings of the 21st International scientific-practical conference. Vol. 4. Moscow: Publishing house GUU, 2016, pp. 250-252.

[8] The program "Digital Economy of the Russian Federation" [Electronic resource] // the Government of Russia. URL: http://government.ru/rugovclassifier/614/events/

[9] N. G. Malyshkin, E. A. Halimon, "Analysis of the level of development of the digital economy of Russia," Vestnik GUU, vol.8, 2018, pp. 79-86.

[10] The decree of the President of the Russian Federation "On introducing changes to the composition of the presidential Council of the Russian Federation for strategic development and national projects, approved by the decree of the President of the Russian Federation of 19 July 2018 N 444" from 19.11.2018 N661 URL: http://kremlin.ru/acts/bank/43769

[11] Verbatim report on the meeting of the presidential Council for strategic development and national projects URL: http://kremlin.ru/events/president/news/58894

[12] L. P. Kanaeva, "Efficiency of implementation of priority national projects in the region," Regionology, vol. 3 (88), 2014, pp. 14-20

[13] The decree of the President of the Russian Federation from 07.05.2018 N 204 "About the national goals and strategic objectives development of the Russian Federation for the period up to 2024" URL: http://kremlin.ru/acts/bank/43027

[14] A. Solodkov, "New may decree of Putin. Main targets" (07.05.2018) RBK URL: https://www.rbc.ru/politics/07/05/2018/5af060c79a79472bc16 ff1f9
[15] A. Nechaev, "Superukaz of Putin requires drastic changes in medicine" (15.05.2018) RIA Novosti URL: https://vz.ru/society/2018/5/15/922553.html

[16] M. Kolomiets, "Putin will be the main theme of the Congress "popular front"," (29.10.2018) Journal Ridus URL: https://www.ridus.ru/news/286432

[17] A. Novoderezhkin, "The state Duma adopted the Federal budget for the year 2019. Surplus of $1.8 \%$ of GDP" (21.11.2018) TASS, Moscow. URL: https://tass.ru/ekonomika/5817589

[18] A. Druzhinin, "Putin spoke about the goals and objectives of the new government" (26.05.2018) RIA Novosti https://ria.ru/20180526/1521449119.html

[19] M. Bussolo, M. E. Davalos, V. Peragine, R. Sundaram, "Towards a new social contract: increased distributional tensions in Europe and Central Asia," Europe and Central Asia studies. Washington, DC: World Bank, 2018. https://openknowledge.worldbank.org/handle/10986/30393

[20] E. A. Khalimon, "The Role of Russia in international projects in the field of education," Vestnik GUU, vol. 10, 2016, pp. 249-253.

[21] A. Aptekman, V. Kalabin, V. Klincov, E. Kuznetsova, V. Kulagin, I. Yasenovec, "Digital Russia: a new reality," 2017. URL: $\quad$ http://www.tadviser.ru/images/c/c2/DigitalRussiareport.pdf (accessed 18.03.2019). [in Rus.].

[22] E. A. Khalimon, M. N. Guseva, I. Z. Kogotkova, I. S. Brikoshina, "Digitalization of the Russian economy: first results," European production of social and behavioural sciences. International scientific and practical conference "Global challenges and prospects for the development of modern economy", Vol. LVII, 2018. Published at the future Academy, Samara, 2019, pp. 199-213.

[23] Yu. Starostina, "Kudrin reported a discrepancy in the financing of national projects for 1 trillion rubles" (16.10.2018) RBC news URL: https://www.rbc.ru/economics/16/10/2018/5bc5f09a9a7947fe 2447ab98

[24] A. Didkovskaya, "Volodin criticized Oreshkin's speech in the state Duma" (06.03.2009) Vedomosti URL: https://www.vedomosti.ru/politics/articles/2019/03/06/795781 -vistuplenie-oreshkina-v-gosdume

[25] E. V. Kopteva, "Assessment and analysis of efficiency indicators of the tax system of the Russian Federation," Young scientist, vol. 21.1, 2015, pp. 125-129.

[26] Official website of Rosstat URL: http://www.gks.ru/wps/wcm/connect/rosstat_main/rosstat/ru/s tatistics/finance/\#

[27] Revenue Statistics, 2018. Tax revenue trends in the OECD. URL: https://www.oecd.org/tax/tax-policy/revenue-statisticshighlights-brochure.pdf

[28] M. Arsic, S. Ranđelović, N. Altiparmakov, "Shadow economy trends in Serbia: 2012-2017," Highlights. Quarterly Monitor, vol. 52. January-March 2018, pp.51-59.

[29] S. P. Kiseleva, V.A. Maraviev, T. S. Smirnova, "Transition to a closed-cycle economy - a way to improve the environmental situation in Russia," Proceedings of the 1st allRussian scientific and practical conference Priority and promising areas of scientific and technical development of the Russian Federation. Moscow: Publishing house of GUU, 2018, pp. 240-245.

[30] E. A. Khalimon, "Development and management of regional programs of social and economic development of regions," Priority and perspective directions of scientific and technical development of the Russian Federation: materials of the 1st all-Russian scientific and practical conference. Moscow: Publishing house GUU, 2019. [in press] 